\title{
Usaha PPUPIK Pembibitan Kambing Perah Unggul dan Olahan Produk Susu Kambing
}

\author{
Sujono, ${ }^{1 *}$ Khotimah, K. $^{1}$ dan Hendra, K. ${ }^{2}$ \\ ${ }^{1}$ Program Studi Peternakan, Universitas Muhammadiyah Malang, Jl. Raya Tlogomas No. 246, Malang \\ ${ }^{2}$ Program Studi Peternakan dan Ekonomi Pembangunan, Universitas Muhammadiyah \\ Malang, Jl. Raya Tlogomas No. 246, Malang \\ *Email korespondensi: sujono_umm64@yahoo.com
}

\begin{abstract}
Abstrak
Kegiatan pengabdian ini berkaitan dengan usaha pembibitan salah satu jenis kambing perah unggul yang belum banyak dibudidayakan masyarakat yaitu kambing Saenen dan pengembangan aneka olahan produk susu kambing. Kambing Saenen memiliki produksi susu paling tinggi mencapai 3-4 liter/hari/ekor dibanding jenis kambing perah lainnya, misalnya Peranakan Etawa. Kegiatan pengabdian dilakukan multitahun (3 tahun) berupa pembibitan kambing perah jenis Saenen, produksi susu kambing segar dan susu kambing olahan (yogurt aneka rasa, es krim, sabun natural susu) serta produksi suplemen mineral ternak perah. Kegiatan Tahun I berupa: penambahan kambing perah Saenen (2 jantan dan 10 dara) dengan total kambing 25 ekor, produksi susu rata-rata 300 liter/bulan, pembuatan susu pasteurisasi aneka rasa 900 cup/bulan, yogurt susu kambing 300 botol/bulan, pembuatan pakan kambing 1 ton/bulan dan es krim bahan dari susu kambing 3000 cup/bulan, dengan melibatkan 6 mahasiswa untuk belajar berwirausaha. Kegiatan tahun ke II berupa: produksi susu rata-rata 450 liter/ bulan, menampung susu kambing peternak 900 - 1200 liter/bulan pembuatan susu pasteurisasi aneka rasa 6000 cup/bulan, yogurt susu kambing 3000 botol/bulan, pembuatan pakan kambing 9 ton/bulan dan es krim bahan dari susu kambing $6000 \mathrm{cup} / \mathrm{bulan}$ serta pengembangan mineral ternak 9-10 ton/bulan. Kesimpulan kegiatan ini adalah perkembangan PPUPIK selama dua tahun sangat bagus dan prospektif sehingga dilanjutkan tahun ketiga.
\end{abstract}

Kata kunci: Kambing Perah Saenen, Produksi Susu, Kambing Etawa

\begin{abstract}
This community service activity is related to the cultivation of one of superior goats husbandry that has not been widely cultivated by the community, namely Saenen goats and the development of various processed goat milk products. Saenen goats have the highest milk production for almost 3-4 liters/day/head compared to other types of dairy goats, for example Etawah crossbred goat. PPUPIK activities has been carried out for 3 years in the form of breeding of Saenen dairy goats, the production of fresh goat's milk and processed goat's milk (various flavored yogurt, ice cream, natural milk soap), and the production of dairy livestock mineral supplements. The first year's activities involving 6 students to learn entrepreneurship included: the addition of Saenen dairy goats $(2$ males and 10 females) with a total of 25 goats; the average of milk production was 300 liters/month; the production of pasteurized milk, goat milk yogurt, and ice cream from goat milk were 900 cups/month, $300 \mathrm{ml} /$ month, and 3000 cups/month, respectively; and the production of goat feed was 1 ton/month. Activities in the second year included: producing goat milk (450 liters/month); collecting goats milk from breeders (900-1200 liters/month); making various flavors of pasteurized milk (6000 cups/month), yogurt goat milk (3000 bottles/month), ice cream from goat milk (6000 cups/month), goat feed (9 tons/month), and producing of livestock minerals (9-10 tons/month). The conclusion for this activity is the development of PPUPIK for two years is good and prospective so that it will be continued on the third year.
\end{abstract}

Keywords: Saenen Dairy Goat, Milk Production, Etawa Goat 
Format Sitasi: Sujono, Khotimah, K. \& Hendra, K. (2019). Usaha PPUPIK Pembibitan Kambing Perah Unggul dan Olahan Produk Susu Kambing. Jurnal SOLMA, 8(2), 330-338, Doi: http://dx.doi.org/10.29405/solma.v8i2.3530

Diterima: 23 Juni 2019 | Revisi: 13 September 2019 | Dipublikasikan: 21 Oktober 2019

(C) 2019. Oleh authors. Lisensi Jurnal Solma, LPPM-Uhamka, Jakarta. Artikel ini bersifat open access yang didistribusikan di bawah syarat dan ketentuan Creative Commons Attribution (CC-BY) license. (http://creativecommons.org/licenses/by/4.0/).

\section{PENDAHULUAN}

Kebutuhan bahan baku susu segar dalam negeri (SSDN) untuk susu olahan saat ini sekitar 3,3 juta ton per tahun, dengan pasokan bahan baku susu segar dalam negeri 690 ribu ton per tahun $(21 \%)$ dan sisanya sebesar 2,61 juta ton (79 \%) masih harus diimpor dalam bentuk skim milk powder, anhydrous milk fat, dan butter milk powder dari berbagai negara seperti Australia, New Zealand, Amerika Serikat, dan Uni Eropa (Kemenperin, 2016). Usaha peternakan sapi perah di dalam negeri belum mampu memenuhinya, sehingga pemasaran susu kambing perah masih terbuka lebar dan memiliki prospek yang cukup cerah. Salah satu potensi ternak lokal sebagai sumber susu yang belum dimanfaatkan secara maksimal adalah kambing perah. Susu kambing sebagai salah satu penyedia pangan asal ternak yang bergizi dan berdaya saing tinggi serta menciptakan lapangan kerja dibidang agribisnis peternakan (Pakage, 2008). Usaha ternak kambing ditinjau dari aspek pengembangan secara komersil sangat potensial dan lebih menguntungkan dibanding usaha sapi perah. Beberapa keuntungan usaha kambing perah diantaranya adalah umur dewasa kelamin dan dewasa tubuh serta lama bunting ternak kambing sangat pendek dibandingkan dengan ternak ruminansia lainnya, sehingga cepat menghasilkan air susu serta biaya produksi lebih murah dibanding usaha sapi perah (Sundari \& Efendi, 2010).

Usaha ternak kambing disektor usaha primer menunjukkan bahwa usaha tersebut memberikan keuntungan yang relatif baik dengan nilai O/I ratio 1,39 (Sodiq \& Abidin, 2008). Usaha ternak kambing tidak saja dapat menciptakan lapangan pekerjaan maupun lapangan usaha, namun juga memberikan penghasilan dan pendapatan Sutama \& Ketut, (2004). Susu kambing telah terbukti kaya manfaat, hal ini sesuai dengan hasil penelitian Darkuni (2001); Purwati, Vebriyanti \& Suharto (2012) yang menyebutkan bahwa susu kambing mengandung lemak dan protein yang sangat dibutuhkan oleh tubuh. Sodiq \& Abidin (2008); Purwati et al. (2012) menyatakan bahwa butiran lemak susu kambing yang berdiameter kecil dan homogen berukuran antara 1-10 milimikron, sehingga susu kambing 
lebih mudah diserap oleh kulit manusia. Kandungan fluorin yang terdapat pada susu kambing berkisar 10 sampai 100 kali lebih besar dibandingkan susu sapi. Kandungan fluorin dalam susu ini bermanfaat sebagai antiseptik alami dan dapat membantu menekan pembiakan bakteri di dalam tubuh (Yudhistiwa \& Puspita, 2014). Menurut hasil pengamatan Naji, (2010); Purwati et al., (2012) susu kambing yang kaya kandungan zat asam beta hidroksil alami dapat dijadikan campuran untuk lulur. Berdasarkan penelitian Radbogmin (2017) bahwa campuran untuk lulur berfungsi sebagai peeling yang mengikis kotoran dan sel kulit mati, namun mampu mencerahkan kulit hingga terlihat lebih halus dan tidak bersisik. Berdasarkan artikel Kosmetologi (2016) bahwa kandungan protein dalam susu juga berguna sebagai suplai nutrisi yang berfungsi melembabkan sekaligus melapisi permukaan kulit agar lebih halus dan kenyal. Untuk itu program Program Pengembangan Produk Usaha Inovasi Kampus (PPUPIK) ini sangat perlu dikembangkan di kampus mulai dari hulu sampai hilir dalam agroindustri kambing perah sebagai income generating lembaga, tempat menggembleng mahasiswa untuk belajar berwirausaha.

Target dan tujuan kegiatan pengabdian PPUPIK ini adalah terbentuknya Pusat Budidaya Kambing Perah Unggul jenis Saenen mulai dari pembuatan pakan, pemeliharaan kambing perah, pembuatan mineral ternak perah, pengolahan pupuk dan pengolahan susu kambing menjadi yogurt, es krim, susu siap minum di Universitas Muhammdiyah Malang sehingga dapat berperan sebagai tempat praktikum mahasiswa berbasis kegiatan produksi susu kambing, tempat penelitian dosen dan mahasiswa, tempat kunjungan dan tempat pelatihan edukasi kambing perah dan olahan pangan asal susu kambing.

\section{METODE PELAKSANAAN}

Mitra kegiatan pengabdian ini melibatkan beberapa mitra diantaranya adalah pertama HMJ (Himpunan Mahasiswa Jurusan) Peternakan, kedua kelompok peternak kambing perah di Kota Batu sebagai tempat penjualan pakan dan mineral serta menampung susu kambing dari peternak dan ketiga Kantin yang ada di kampus sebagai tempat pemasaran olahan produk susu, keempat PT. Sinar Mentari di Blitar untuk pembuatan pakan dalam bentuk pellet. Kegiatan agro industri kambing perah ini dilaksanakan melalui beberapa tahap yaitu perencanaan kegiatan, pelaksanaan kegiatan dan evaluasi. Perencanaan kegiatan diawali dengan melakukan identifikasi kesiapan pelaksanaan kegiatan seperti kesiapan mencari induk dan pejantan kambing perah Saenen yang unggul, mencari informasi suplier bahan pakan ternak, sarana prasarana produksi susu siap minum, es krim 
dan yoghurt, manajemen, pemasaran, sumberdaya manusia, dan kebutuhan pendanaan kegiatan. Setelah semua data teridentifikasi maka dibuat target capaian kegiatan yang terukur dan terjadwal, sebagai acuan dalam pelaksanaan kegiatan.

Kegiatan tahun pertama diawali dengan upaya peningkatan produksi susu karena kurangnya permintaan susu segar dengan penambahan populasi kambing perah jenis unggul yaitu pejantan dan induk kambing Saenen. Selanjutnya perbaikan dan penambahan kandang, pengadaan alat-alat pengolah susu (mesin es krim, alat pasteurisasi), pengadaan mesin pencacah pupuk, pengadaan freezer untuk menyimpan susu kambing dan penataan SDM.

\section{Proses Produksi}

Susu segar, es krim, yoghurt, mineral sebagai feed suplement ternak dan pakan kambing siap saji yang diproduksi ini telah melalui serangkaian penelitian dan quality control untuk menjaga kualitas produk dilakukan di laboratorium teknologi hasil pangan, Lab. nutrisi dan pakan milik Fakultas Pertanian Peternakan serta kontrol mikroba dan residu kimia dilakukan di laboratorium Mikrobiologi Universitas Muhammadiyah Malang. Formula pakan dan formula mineral merupakan hasil serangkaian penelitian yang dilakukan (Sujono, 2016; Sujono \& Yani, 2013). Bagan alur proses produksi budidaya kambing perah secara integratif adalah sebagai berikut (Gambar 1).

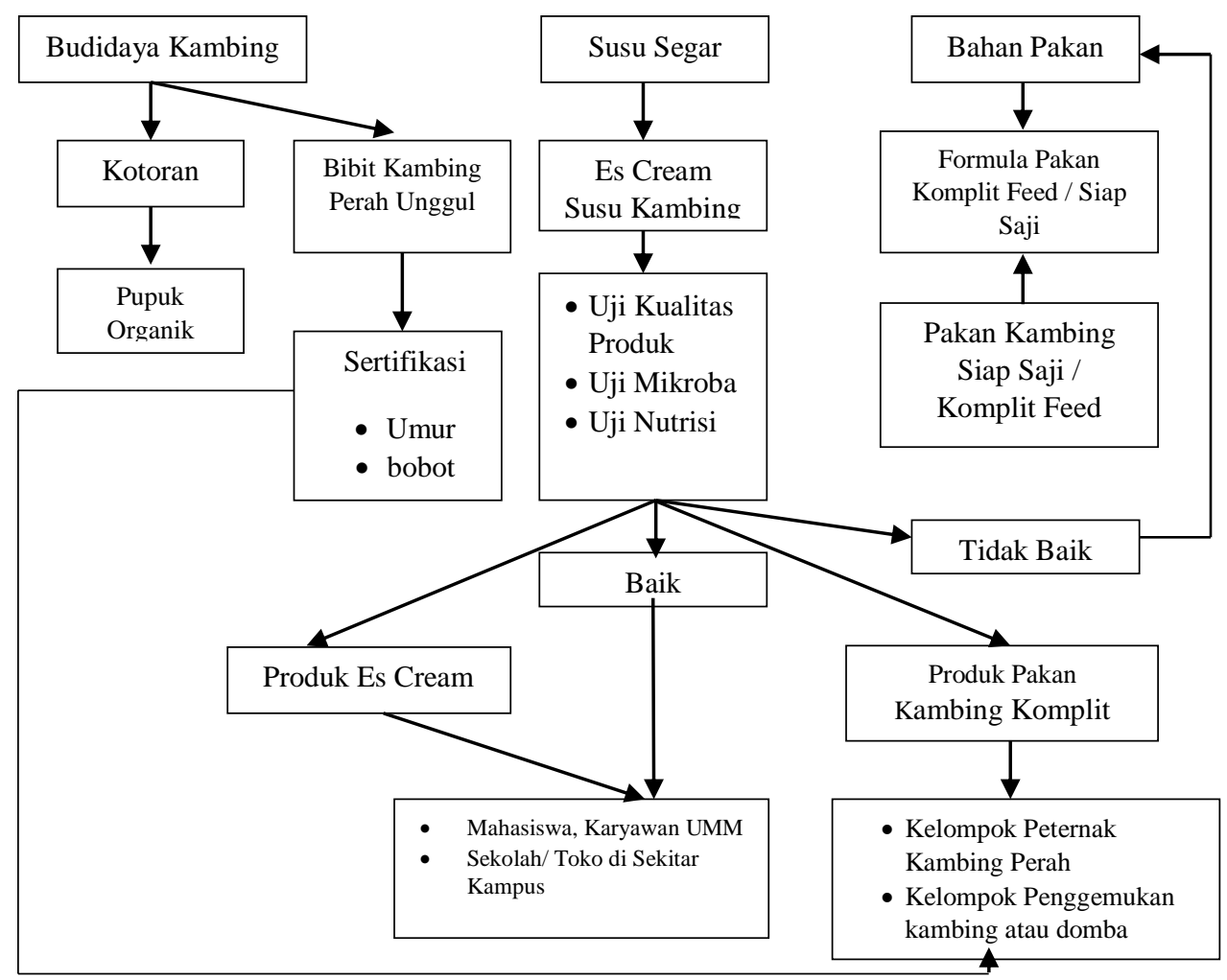


Gambar 1. Alur Proses Budidaya Kambing Perah Secara Terpadu

Evaluasi merupakan kegiatan mengkaji rangkaian pelaksanaan kegiatan secara keseluruhan serta mengindentifikasi kendala-kendala dalam pelaksanaan kegiatan. Evaluasi dilakukan oleh seluruh tim yang terlibat dalam kegiatan, dan hasil evaluasi dipakai untuk perbaikan rencana kegiatan di tahun berikutnya.

\section{HASIL DAN PEMBAHASAN}

\section{Populasi Kambing Perah}

Awal kegiatan tahun pertama hanya memiliki 15 ekor induk kambing Sapera dan satu pejantan Saenen dengan produksi susu 8-10 liter/hari. Pengadaan kambing tahun pertama dengan menambah 4 induk kambing Saenen dan 4 ekor induk Senduro dan tahun kedua pengadaan 8 ekor kambing Saenen dara. Adapun total populasi saat ini pejantan Saenen 1 ekor, induk 45 ekor, dara 8 ekor, jantan muda 3 ekor, anak kambing 18 ekor (Gambar 2). Perkembangan populasi sampai dengan 2 tahun meningkat 4 kali lipat. Produksi susu pada tahun kedua 25-30 liter/hari dan meningkat 3 kali.

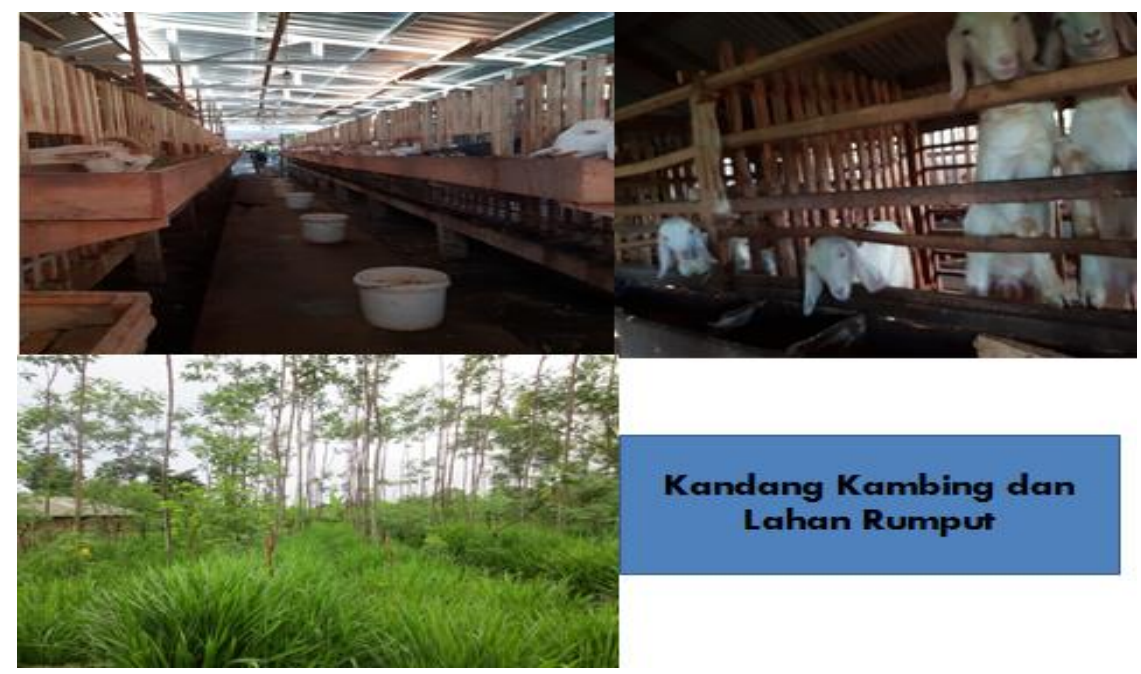

Gambar 2. Kandang Kambing dan Lahan Rumput. Kondisi Kandang dan Ternak Kambing Saenen serta Lahan Hjauan Pakan Ternak.

\section{Pembuatan Es Krim}

Pengolahan susu kambing menjadi produk es krim untuk menambah nilai jual susu kambing dijual segar Rp.16.000/liter meningkat menjadi 100\%. Selain itu juga melihat perkembangan Kota Malang dan Batu yang sangat prospek untuk pemasaran es krim. Produksi es krim tahun kedua meningkat dari 100 cup per hari menjadi 200 cup/hari. Pemasaran semula di kantin 4 sekolah SD dan SMP di Kota Batu, tahun kedua sudah di kantin kampus III UMM dan kantin kampus sekitar UMM. Prospek es 
krim ini menjanjikan karena Kota Malang dan Kota Batu sebagai pusat pendidikan dan wisata. Kendala masih tempat penyimpanan yang harus menyediakan pendingin sendiri.

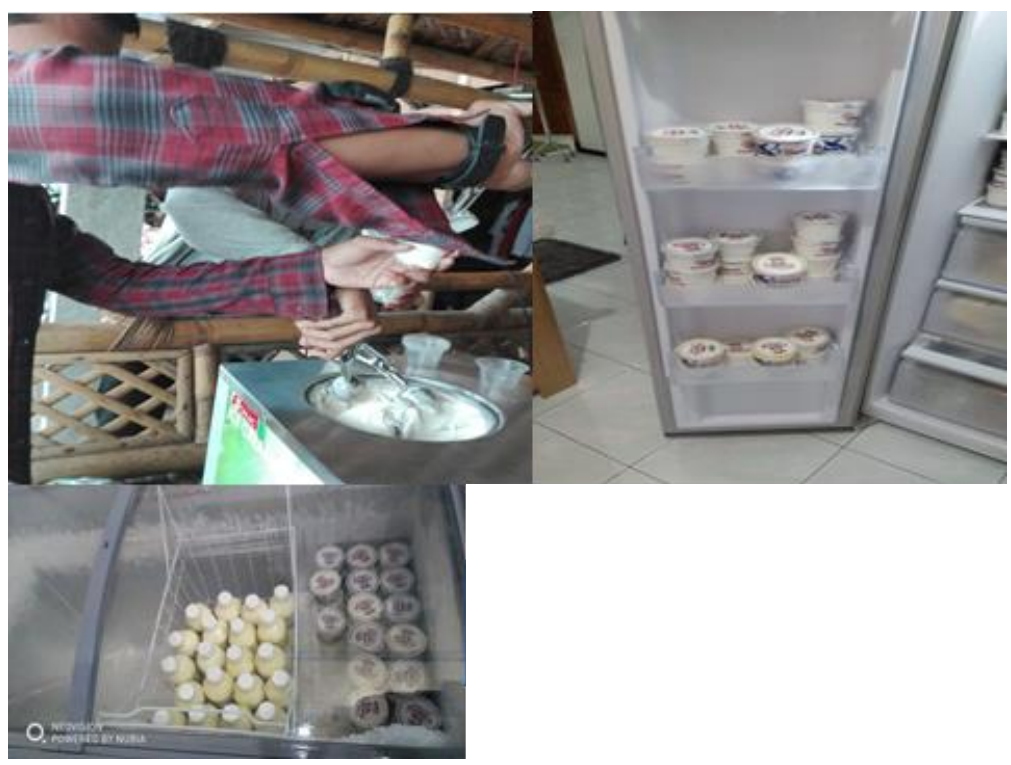

Gambar 3. Produk es krim susu kambing dan proses pembuatan es krim berbahan susu kambing

\section{Pembuatan Pakan Ternak}

Kapasitas pasar pakan ternak PPUBIK tahun kedua mengalami peningkatan besar mencapai 9 ton/bulan dari tahun sebelumnya hanya 3 ton/bulan. Hal ini karena ada tambahan pasar baru yaitu di kelompok ternak sapi perah Kecamatan Pulung dan Kecamatan Pendak Kabupaten Ponorogo. Jenis pakan ternak yang diproduksi adalah pakan kambing, pakan sapi perah, pakan kelinci dan pakan penggemukan untuk domba dalam bentuk pellet kerjasama dengan PT. Sinar Mentari Group di Blitar sebagai tempat pembuatan pakan pellet. Usaha pakan pellet ini memiliki prospek karena harga lebih murah hanya Rp. 4.500/kg dibanding pakan pabrik yang mencapai Rp.7000/kg dan wilayah Malang merupakan sentra sapi perah dan kambing perah.

\section{Pembuatan Susu Pasterisasi dan Yoghurt Susu Kambing}

Olahan susu kambing yang dilakukan pada tahun kedua dengan menambah produk baru yaitu yogurt susu kambing kemasan $250 \mathrm{ml}$. Kapasitas produksi susu pasteurisasi mencapai 200 gelas/hari dipasarkan di tempat wisata di Kota Batu. Kapasitas produksi yogurt susu kambing dengan rasa coklat dan strawberry mencapai 50 botol/hari dipasarkan di outlet toko koperasi UMM dan Rumah sakit. Karena yoghurt ini biasa dikonsumsi oleh penderita kencing manis, kolesterol dan magh 
sebagai upaya untuk memulihkan kesehatannya dan berdasarkan penelitian Maria Rosiana \& Khoiriyah (2018) bahwa yoghurt mengandung antioksidan dan rendah gula. Sedangkan usaha STMJ ditutup karena sewa tempat yang tidak menguntungkan.

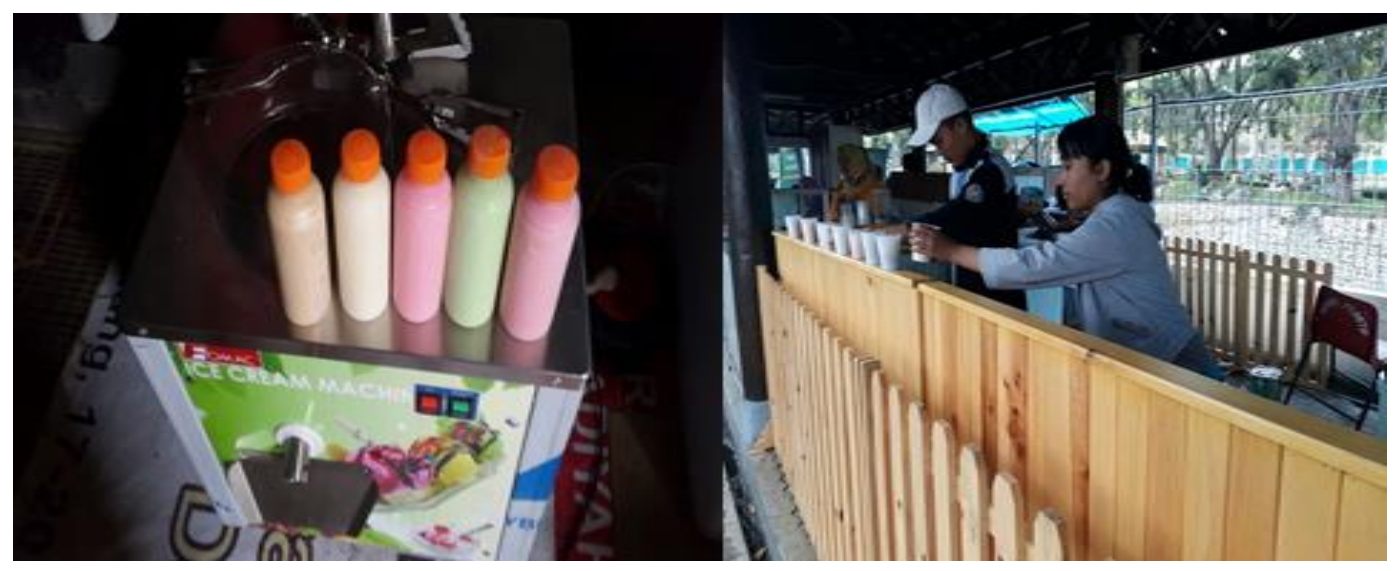

Gambar 4. Produk susu kambing pasteurisasi, yoghurt aneka rasa dan outlet penjualan susu kambing pasteurisasi aneka rasa.

\section{Mineral Ternak Merk Unggul}

Tahun kedua program PUBIKK ini adalah dengan menambah produk baru hasil riset Sujono (2016) berupa produk mineral untuk ternak perah (sapi dan kambing). Kapasitas produksi sudah mencapai 10 ton/bulan, dipasarkan di sentra-sentra ternak perah di wilayah Malang Raya dan Pasuruan. Mineral merk Unggul yang diproduksi sangat diminati oleh peternak karena harganya murah dengan hasil yang tidak kalah dengan produksi pabrikan. Penggunaan mineral ternak ini ternyata mampu mencegah kelumpuhan pada induk sapi perah yang produksi di atas 20 liter/hari (Simamora, Fuah, \& Atabany 2015).

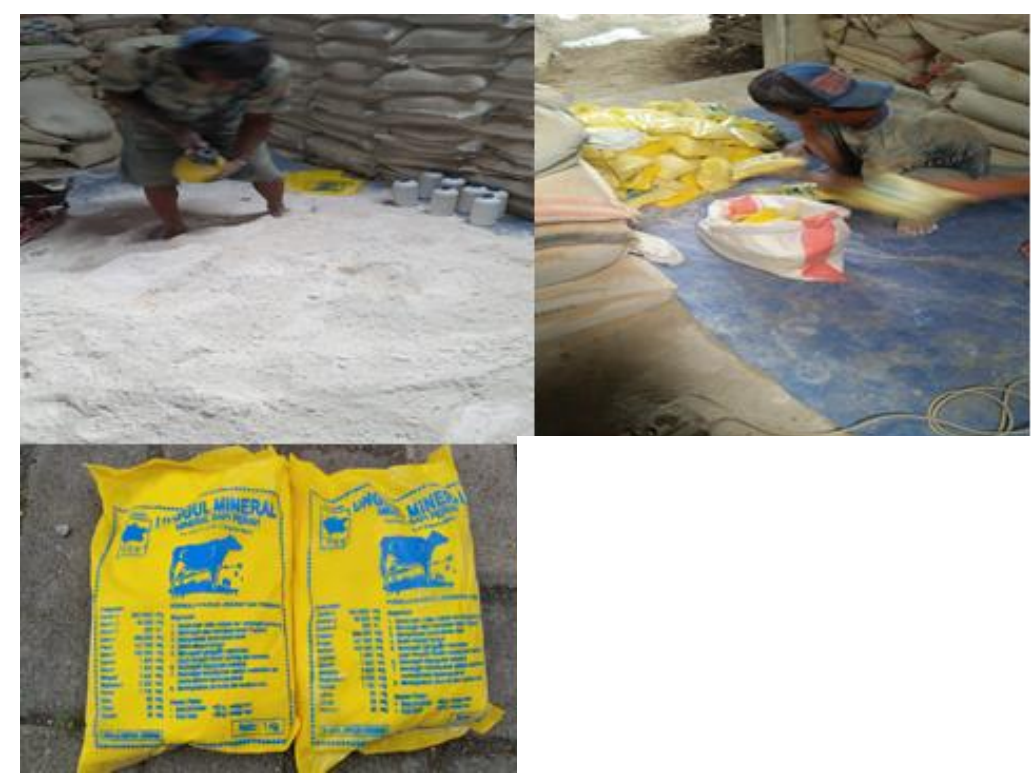


Gambar 5. Pengemasan mineral ternak perah suplemen pakan dan proses pembuatan mineral untuk campuran pakan ternak

\section{Rekruitmen Tenaga Kerja}

Kegiatan PUPIKK tahun kedua ini mampu menambah tenaga kerja. Tenaga kerja yang mengelola kandang untuk budidaya kambing perah 3 orang, untuk pengolahan susu 3 mahasiswa HMJ dan tenaga pemroses mineral dan pakan 3 orang. Untuk pemsaran olahan susu bekerjasama dengan mahasiswa HMJ Peternakan.

\section{KESIMPULAN}

Hasil Kegiatan pengabdian ini dapat disimpulkan bahwa skim pengabdian PPUPIK sangat membantu membangun income generating lembaga, membantu membangun semangat dan jiwa wirausaha mahasiswa dalam budidaya kambing perah dan pemasaran produk dan produk yang memiliki omset paling tinggi adalah penjualan susu segar dan mineral dibanding produk yang lain. Harapan kami budidaya kambing perah dan aneka olahan pangan asal susu kambing perlu dimasukkan sebagai salah satu tema mata kuliah kewirausahaan untuk memperkuat sikap dan mental jiwa wirausaha mahasiswa.

\section{DAFTAR PUSTAKA}

Darkuni, N. (2001). Mikrobiologi. Malang: JICA.

Kemenperin. (2016). Konsumsi Susu Masih 11,09 Liter per Kapita. Retrieved October 9, 2019, from Kementrian Perindustrian RI website: https://kemenperin.go.id/artikel/8890/Konsumsi-Susu-Masih-11,09-Liter-per-Kapita

Kosmetologi. (2016). Lulur. Retrieved October 9, 2019, from Zollavs.com website: https://zollavs.com/2016/03/kosmetologi-lulur.html

Maria Rosiana, N., \& Khoiriyah, T. (2018). Yogurt Tinggi Antioksidan dan Rendah Gula dari Sari Buah Apel Rome Beauty dan Madu. Jurnal Ilmu Dan Teknologi Hasil Ternak, 13(2), 81-90. https://doi.org/10.21776/ub.jitek.2018.013.02.2

Naji, S. Manfaat susu untuk kecantikan. , (2010).

Pakage, S. (2008). Analisis Pendapatan Peternak Kambing di Kota Malang (Income Analyzing Of Goat Farmer at Malang). Jurnal Ilmu Perternakan, 3(2), 51-57. Retrieved from https://www.researchgate.net/publication/325825519_Analisis_Pendapatan_Peternak_ Kambing_di_Kota_Malang_Income_Analyzing_Of_Goat_Farmer_at_Malang

Purwati, E., Vebriyanti, E., \& Suharto, E. L. S. (2012). Sabun Susu Kambing Virgin Coconut Oil Dapat Meningkatkan Kesehatan Kulit Melalui pH dan Bakteri Baik (Bakteri Asam Laktat) serta Meningkatkan Pendapatan Masyarakat. Prosiding 
Seminas,

$1(2)$.

Retrieved

from

http://journal.unipdu.ac.id:8080/index.php/seminas/article/view/158

Radbogmin. (2017). Relaksasi dengan Lulur Domba. Retrieved October 9, 2019, from Radar Bogor website: http://www.radarbogor.id/2017/11/18/relaksasi-dengan-lulurdomba/

Simamora, T., Fuah, A. M., \& Atabany, A. (2015). Evaluasi Aspek Teknis Peternakan Sapi Perah Rakyat di Kabupaten Karo Sumatera Utara Evaluation of Technical aspects on Smallholder Dairy Farm in Karo Regency of North Sumatera. Jurnal Ilmu Produksi Dan Teknologi Hasil Peternakan, 3(1), 52-58. https://doi.org/10.29244/jipthp.3.1.5258

Sodiq \& Abidin. (2008). Meningkatkan Produksi Susu Kambing Peranakan Etawa. Jakarta: Agromedia Pustaka.

Sujono. (2016). Pemberdayaan Warga Panti Pesantren Mandiri Mahasiswa dengan Model Pertanian Integratif. Seminar Nasional Dan Gelar Produk, 252-255. Retrieved from http://research-report.umm.ac.id/index.php/research-report/article/viewFile/773/991

Sujono \& Yani, A. (2013). Produksi Dan Kualitas Air Susu Kambing Etawa Dengan Berbagai Formula Pakan Penguat Di Usaha Peternakan Kambing Etawa Kota Batu. In Laporan Penelitian Dana DPP-UMM. Malang: DPPM Universitas Muhammadiyah Malang.

Sundari dan Efendi, K. (2010). Analisis Pendapatan dan Kelayakan Usaha Peternak Kambing Peranakan Etawah di Kecamatan Girimulyo Kabupaten Kulonprogo. Jurnal Agri Sains, 1(1), 23-30. Retrieved from http://lppm.mercubuana-yogya.ac.id/wpcontent/uploads/2014/12/Analisis-Pendapatan-Dan-Kelayakan-Usaha-PeternakKambing-Peranakan-Etawah-Di-Kecamatan-Girimulyo-Kabupaten-Kulonprogo.pdf

Sutama \& Ketut, I. (2004). Teknologi Reproduksi Ternak Kambing. In Temu Aplikasi Paket Teknologi Pertanian. NTB: BPTP Nusa Tenggara Barat.

Yudhistiwa, A., P, A. A., \& Puspita, D. Yoghurt "HCPT" (High Calorie and Protein for Tuberculosis Disease) dengan formulasi sinbiotik kacang merah dan susu kambing dalam daya hambat myobacterium tuberculosis. (2014). 